\title{
Inváziós fajok előfordulása és kezelése Magyarország védett és Natura 2000 területein, európai összehasonlítással
}

\author{
Kézdy Pál ${ }^{1}$, Csiszár Ágnes², Korda Márton² és Bartha Dénes ${ }^{2}$ \\ ${ }^{1}$ Duna-Ipoly Nemzeti Park Igazgatóság 1121 Budapest, Költö u. 21. \\ ${ }^{2}$ Soproni Egyetem, Erdömérnöki Kar, Növénytani és Természetvédelmi Intézet \\ 9400 Sopron, Bajcsy-Zsilinszky u. 4. \\ e-mail:kezdyp@dinpi.hu
}

\begin{abstract}
Összefoglaló: A hazánk védett területein előforduló inváziós fajokkal kapcsolatos problémák vizsgálatára kérdőíves felmérést végeztünk a természetvédelmi kezelök körében. A 144 hazai védett területről kapott válaszokat összehasonlítottuk Genovesi \& Monaco (2014) vizsgálatával, akik 21 európai országból 138 védett terület kezelőinek válaszait dolgozták fel. A legsúlyosabb veszélyeztető tényezőket tekintve az európai vizsgálatnál első helyen az élőhelyvesztés és fragmentáció, míg a másodikon az inváziós fajok szerepelnek. Ezzel szemben Magyarországon az inváziós fajok kerültek az első helyre. A 10 legveszélyesebb inváziós állatfaj között 5 halfajt és két vadászati céllal betelepített nagyvadfajt is találunk. A legtöbb területről a házi macskát (Felis catus) és a harlekinkaticát (Harmonia axyridis) említették. A 10 legproblémásabbnak bizonyult növényfaj közül 8 észak-amerikai eredetű, 7 fásszárú. Közülük a legtöbb területröl (66\%) a fehér akácot (Robinia pseudoacacia) jelezték. A Magyarországon természetvédelmi szempontból problémát jelentő fajok közül csak néhány szerepel az Unió számára veszélyt jelentő idegenhonos inváziós fajok jegyzékén. Megoldást jelentene, a regionális, illetve nemzeti jegyzékek differenciált összeállítása, vagyis, ha külön kezelnénk azokat a fajokat, melyeknél az elérni kívánt cél a teljes kiirtás, és azokat, amelyeknél a cél az, hogy a védett és Natura 2000 területekről kiszorítsuk őket.
\end{abstract}

Kulcsszavak: idegenhonos fajok, inváziós fajok, biológiai invázió, Natura 2000, védett területek, kérdöív, Robinia pseudoacacia

\section{Bevezetés}

\section{Hazai invázióbiológiai kutatások és fajlisták}

A rendszerváltozással együtt megváltozott tájhasználat kedvezett az inváziós növények elöretörésének (Botta-Dukát 2017). Ennek a kihívásnak eredményeként egyre több, az inváziós növényfajokkal foglalkozó publikáció jelent meg, bővülő fajlistákat tartalmazva. Az első jelentős lépés az egyre bővülő tudásanyagot 
összegyüjtő Özönnövények (Mihály \& Botta-Dukát 2004) és Özönnövények II. (Botta-Dukát \& Mihály 2006) címü kötetek megjelenése volt. Az első kötetben Balogh et al. (2004) 71 inváziós, 76 meghonosodott, de nem inváziós, és 569 alkalmi megjelenésủ adventív fajt sorol fel. Az Inváziós növényfajok Magyarországon címủ könyv (Csiszár 2012) 74 inváziós vagy potenciálisan inváziós fajt mutat be. Bartha et al. (2015) az őshonos fajoké mellett az idegenhonos növények aktuális hazai elterjedési térképeit is közli. Az említett összefoglaló munkákon kívül az invázióbiológia témakörében számos publikáció jelent meg, amelyek egyaránt érintik az inváziós fajok elterjedésére (Balogh et al. 2008, Kazinczi et al. 2008, Király et al. 2008, Török et al. 2003) és az elözönlött élőhelyekre vonatkozó témaköröket (Balogh 2001, Botta-Dukát 2008, Csecserits et al. 2016). A felsorolt publikációk többnyire csak érintőlegesen említik a fajok visszaszorításának gyakorlati vonatkozásait. Ezt a hiányt pótolja az Özönnövények visszaszoritásának gyakorlati tapasztalatai címủ kötet (Csiszár \& Korda 2017).

Az inváziós állatfajok kutatására vonatkozóan alapos áttekintést nyújt a $M a-$ gyar Tudomány tematikus száma (Papp 2017). A hazai vonatkozású publikációk az egyes rendszertani kategóriákat illetően nem kiegyenlítettek. Báldi \& Soltész (2017) megállapítása szerint inváziós szempontból eddig a vízben élő állatfajokat kutatták a legjobban. A vízi özönfajokkal foglalkoznak többek között Balogh et al. (2008), Bódis (2007), Bódis et al. (2011a, 2011b, 2012, 2014), Borza (2009, 2011), Borza et al. (2011), Csányi (1999), Muskó és Bakó (2005), Muskó et al. (2007, 2008), Takács et al. (2017) és Weiperth et al. (2011, 2017) cikkei. Számos kutatás foglalkozott az ízeltlábúakkal is (Csóka et al. 2012, Ripka 2010, Szeőke \& Csóka 2012, Tuba et al. 2012, Merkl 2017).

A Vidékfejlesztési Minisztérium 2010-ben Inváziós Szakértői Tanácsot hozott létre. Munkájuk eredményeként születtek meg A természetes állat-és növényvilágra veszélyt jelentő idegenhonos inváziós fajok hazai tudományos alapú jegyzékei (Természetvédelem 2017).

\section{Nemzetközi listák}

Az inváziós növény- és állatfajokról, illetve veszélyességükről számos, eltérő szempontú és területi léptékủ lista készült. Európa területére vonatkozóan a DAISIE projekt keretében invázióbiológiával foglakozó kutatók állítottak össze egy listát az idegenhonos fajokról, ami 10771 taxont tartalmaz, továbbá közölték a 100 legnagyobb veszélyt jelentő faj listáját is (DAISIE, 2009). Az European and Mediterranien Plant Protection Organization (EPPO) a növényfajokra vonatkozóan, veszélyességük szerint rangsorolva öt listát tett közzé: 1. Lists of pests recommended for regulation as quarantine pests (Olyan fajok listája, amelyeket karantén károsítóként javasolnak szabályozni), 2. List of invasive alien plants (In- 
váziós idegen növényfajok listája), 3. Observation List of invasive alien plants (Megfigyelendő inváziós idegen növényfajok listája), 4. Alert List (Riasztási lista), 5. Other documented plant species (Egyéb dokumentált növényfajok) (EPPO 2017).

Ezekhez a listákhoz képest új megközelítést jelentett Genovesi \& Monaco (2014) vizsgálata, akik azt mérték fel, hogy a védett területek kezelői mely inváziós fajokat tartják a legveszélyesebbeknek. Itt tehát elsősorban a természetvédelmi kezelési tevékenység során szerzett tapasztalatok kerültek elötérbe. Az általuk végzett kérdőíves felmérésre 21 európai országból 138 válasz érkezett. Mindezek a tengerpartoktól a magashegységekig terjedő élőhelyeket ölelnek fel, ugyanakkor Magyarországi védett terület nem került a vizsgálatba. Ezt a kérdőíves felmérést ismételtük meg a hazai védett területek természetvédelmi kezelőinek körében, aminek eredményeit az alábbiakban ismertetjük.

\section{Módszerek}

A magyarországi védett területeken előforduló inváziós fajokkal kapcsolatos problémák megismerésére kérdőíves felmérést végeztünk. Annak érdekében, hogy az eredmények összehasonlíthatók legyenek a Genovesi \& Monaco (2014) által közölt európai eredményekkel, az általuk használt kérdőívet lefordítottuk magyarra, változatlan tartalommal. Az internetes felméréshez hozzájuk hasonlóan a SurveyMonkey programot használtuk.

Az adatok gyüjtése 2016. október-december között történt. A kérdőíveket a magyarországi védett területek (nemzeti parkok, tájvédelmi körzetek, természetvédelmi területek, Natura 2000 területek) természetvédelmi kezeléséért felelős 10 nemzeti park igazgatóság dolgozóinak küldtük szét. A kérdőívet bármelyik fenti védettségi kategóriába tartozó területre vonatkozóan ki lehetett tölteni, de az fontos feltétel volt, hogy az egyes területek ne fedjenek át. Amennyiben ez nem teljesült, akkor csak az egyik kérdőívet vettük figyelembe. Ezekben az esetekben egyedi mérlegelés alapján döntöttünk. Több védett terület nem szerepelhetett egy kérdőíven, de arra lehetőség volt, hogy egy védett terület jól beazonosítható részterületére külön kérdőív szülessen. Ez történt például a Kiskunsági Nemzeti Park esetében, ami kilenc, egymással nem érintkező részterületből áll. Azokat a kérdőíveket, amelyeknél a terület nem volt egyértelmüen azonosítható, kizártuk a vizsgálatból. Az előzetes szürés után 73 adatközlö, összesen 144 értékelhető kérdőíve maradt a vizsgálatban. Mind a 10 nemzeti park igazgatóság területéről, sík- és dombvidéki, illetve középhegységi élőhelyekről is kaptunk válaszokat, így a felmérés jól reprezentálja a magyarországi védett területeket. 
Azoknál a kérdéseknél, ahol a vizsgált tényezőt 1-5 értékkel lehetett osztályozni, kumulatív értéket számoltunk, vagyis az 1-es értéket 5-tel szoroztuk, a 2-est 4-gyel stb. és az így kapott szorzatokat vizsgált tényezőnként összegeztük. Az eredmények interpretációjánál a kumulatív értékkel megjelenített diagramok esetében az európai és magyarországi vizsgálat eredményét azonos skálán ábrázoltuk, mivel a két vizsgálatnál megközelítőleg azonos számú (138 és 144) válasz érkezett. Meg kell jegyezni, hogy a magyarországi adatszolgáltatók általában sokkal magasabb értékeket jelöltek meg, mint ami az európai vizsgálatnál látható.

\section{Eredmények}

Az alábbiakban közöljük az egyes kérdésekre adott magyarországi válaszok öszszesítését (magyarországi felmérés) és emellett a Genovesi \& Monaco (2014) által közölt európai eredményeket is (európai felmérés).

\section{Véleménye szerint melyek a legsúlyosabb veszélyeztetö tényezök a védett területen?}

$\mathrm{Az}$ 1. ábra a védett területeket érintő legsúlyosabb veszélyeztető tényezőket mutatja be. A kérdőíven lehetőség volt egyéb tényezőket is megnevezni. A magyarországi válaszok között ebben a kategóriában legnagyobb súllyal olyanok szerepeltek, amelyek besorolhatók az „erőforrások kizsákmányolása” kategóriába (helytelen erdőgazdálkodás, túlszaporodott vadállomány, intenzív mezőgazdálkodás). Ezeken kívül ugyancsak nagy súllyal szerepeltek olyan hatások, amik kedvezőtlen szukcessziós folyamatokként foglalhatók össze (pl.: nádasodás, a

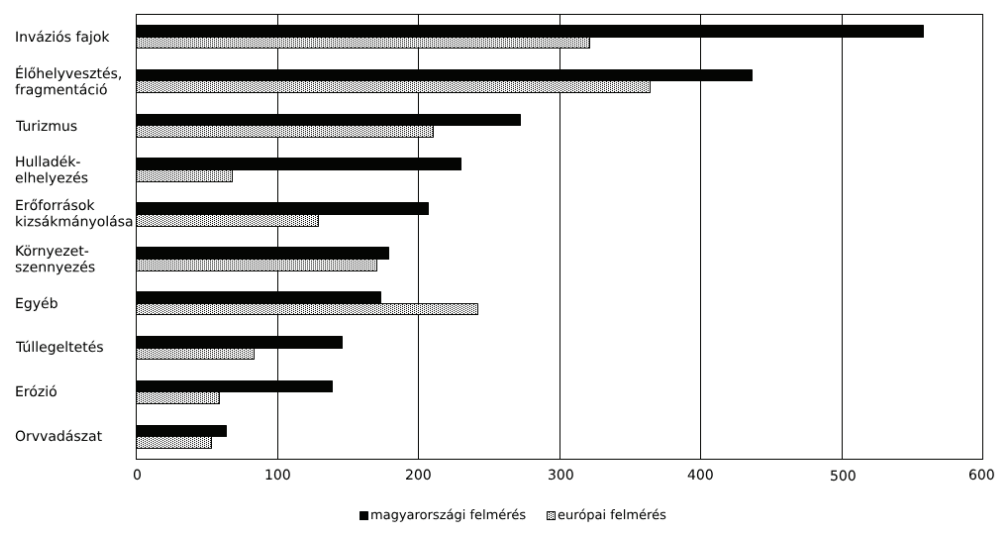

1. ábra: A legsúlyosabb veszélyeztető tényezők Magyarország és Európa védett, illetve Natura 2000 területein (kumulatív értékek). 
Calamagrostis epigeios térfoglalása, beerdősödés, cserjésedés). További jelentős hatások a gyepterületek kezelésének, különösen a legeltetésnek az elmaradása, valamint a vízügyi beavatkozások és a klímaváltozás következtében bekövetkező szárazodás.

\section{Készült-e jegyzék a területen elöforduló idegenhonos fajokról?}

Az 1. táblázat mutatja be, hogy az európai és magyarországi vizsgálat eredménye szerint a védett területek hány százalékában készült felmérés az inváziós növényés állatfajokra vonatkozóan.

1. táblázat: Inváziós növény- és állatfajokra vonatkozó felmérések Európa és Magyarország védett, illetve Natura 2000 területein.

\begin{tabular}{|c|c|c|c|c|}
\hline \multirow{2}{*}{$\begin{array}{l}\text { Készült-e } \\
\text { felmérés? }\end{array}$} & \multicolumn{2}{|c|}{ Állatok } & \multicolumn{2}{|c|}{ Növények } \\
\hline & $\begin{array}{c}\text { európai } \\
\text { területek (\%) }\end{array}$ & $\begin{array}{c}\text { magyarországi } \\
\text { területek }(\%)\end{array}$ & $\begin{array}{c}\text { európai } \\
\text { területek (\%) }\end{array}$ & $\begin{array}{c}\text { magyarországi } \\
\text { területek }(\%)\end{array}$ \\
\hline igen & 37 & 5 & 52 & 37 \\
\hline részben & 21 & 15 & 27 & 48 \\
\hline nem & 42 & 80 & 21 & 15 \\
\hline
\end{tabular}

3. Milyen természetvédelmi intézkedések történtek, amelyek érintik az inváziós állatfajokat a területen? (2. ábra)

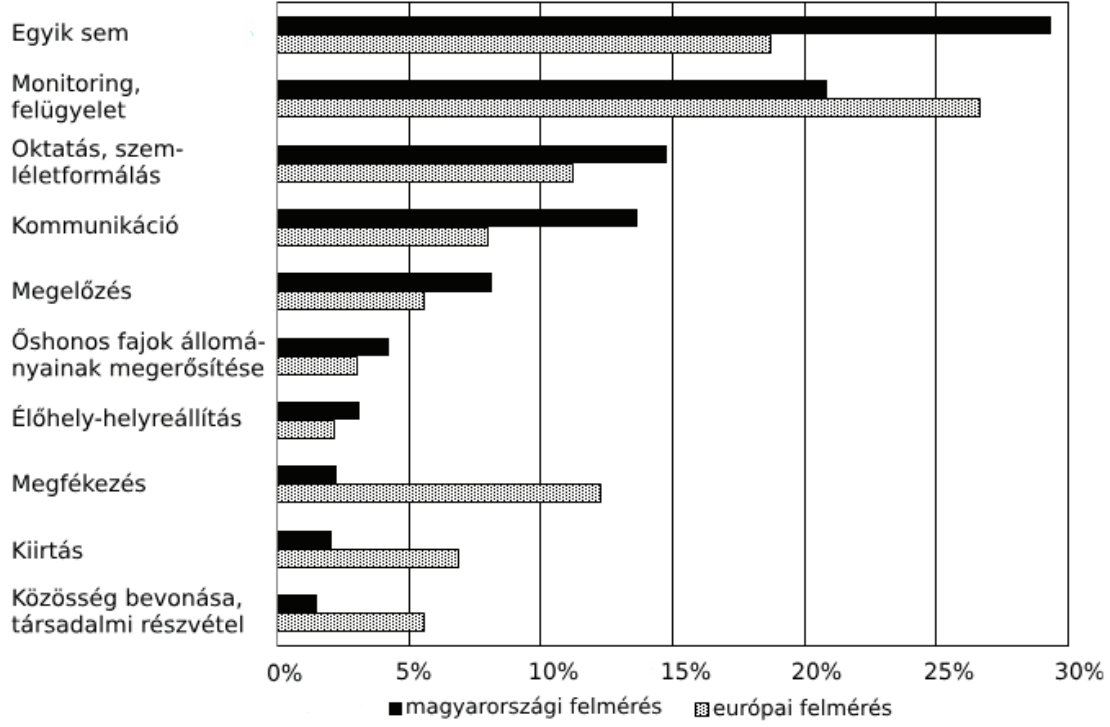

2. ábra: Inváziós állatfajokat érintő legfontosabb intézkedések Magyarország és Európa védett, illetve Natura 2000 területein. 
4. Milyen természetvédelmi intézkedések történtek, amelyek érintik az inváziós növényfajokat a területen? (3. ábra)

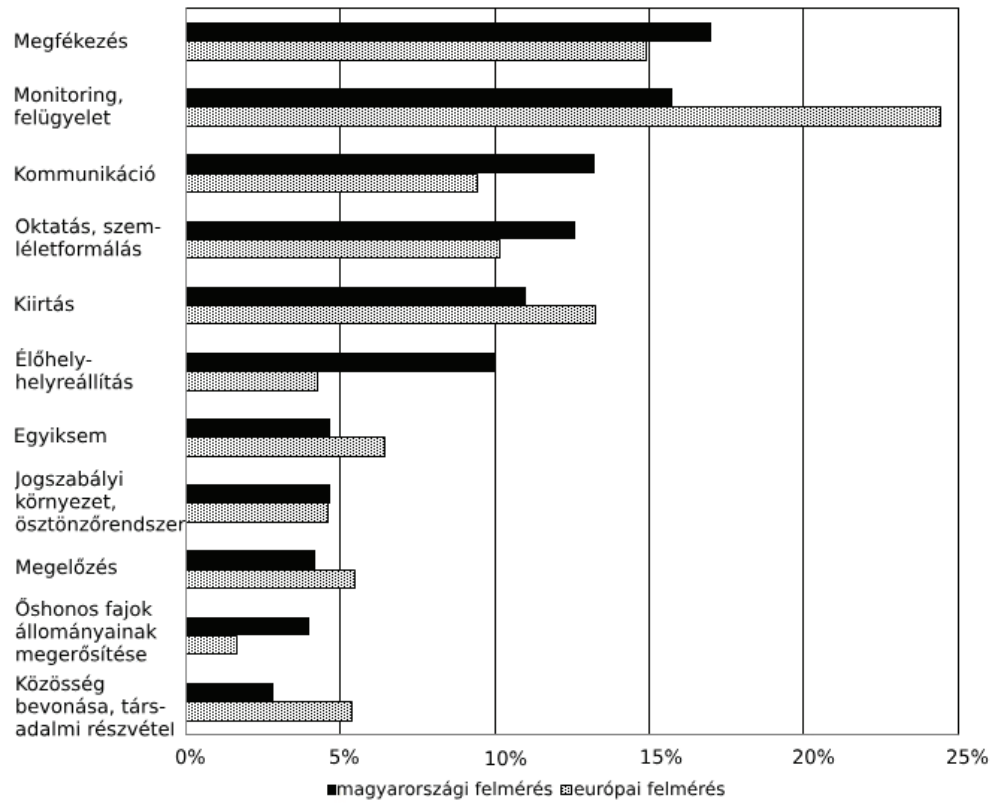

3. ábra: Inváziós növényfajokat érintő legfontosabb intézkedések Magyarország és Európa védett, illetve Natura 2000 területein.

\section{Az inváziós fajok hatásai közül véleménye szerint melyek érintik} legsúlyosabban a területen? (4. ábra)

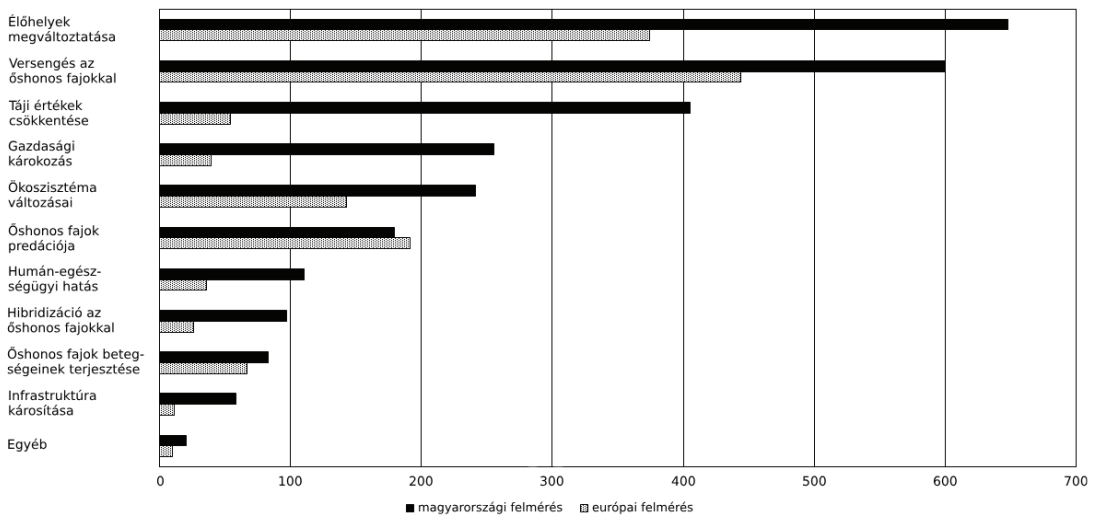

4. ábra: A biológiai invázió legsúlyosabb hatásai Magyarország és Európa védett, illetve Natura 2000 területein (kumulatív értékek). 
6. Véleménye szerint milyen módszerekkel lehet a leghatékonyabban küzdeni az inváziós fajok terjedése ellen a területen? (5. ábra)

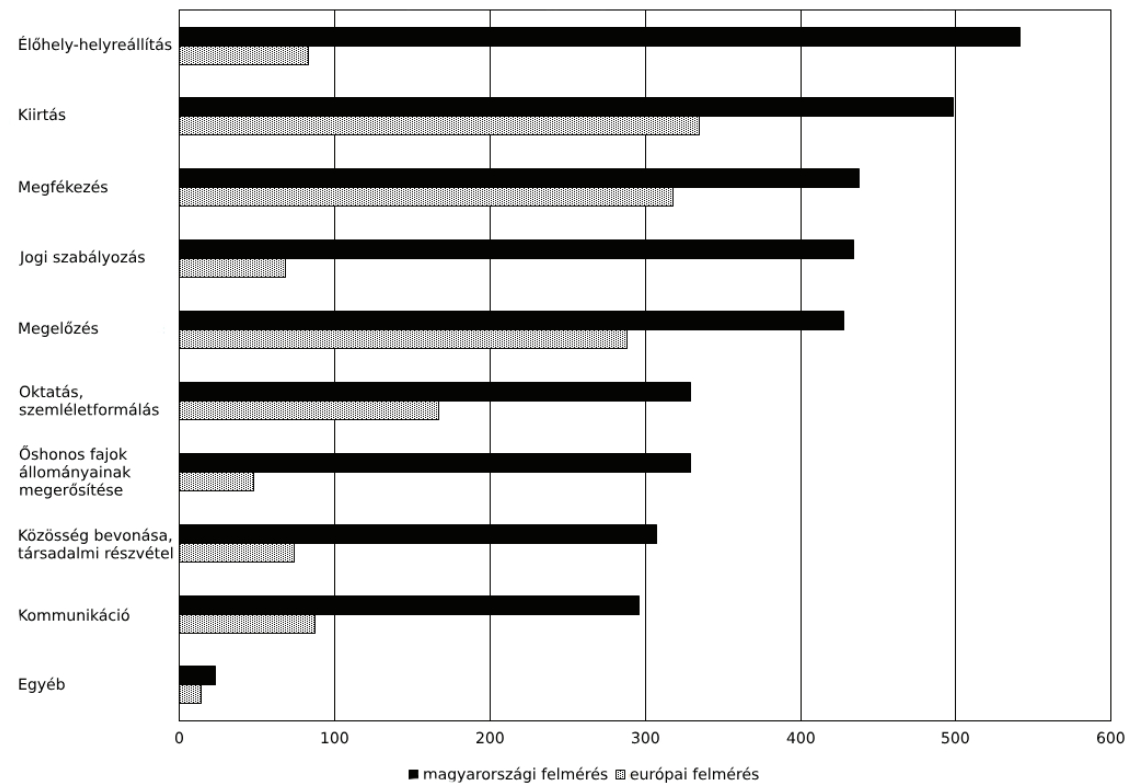

5. ábra: Leghatékonyabb módszerek az inváziós fajok terjedése ellen Magyarország és Európa védett, illetve Natura 2000 területein (kumulatív értékek).

7. Véleménye szerint melyek azok a kulcstényezők, amelyek leginkább hátráltatják az inváziós fajok elleni küzdelmet a területen? (6. ábra)

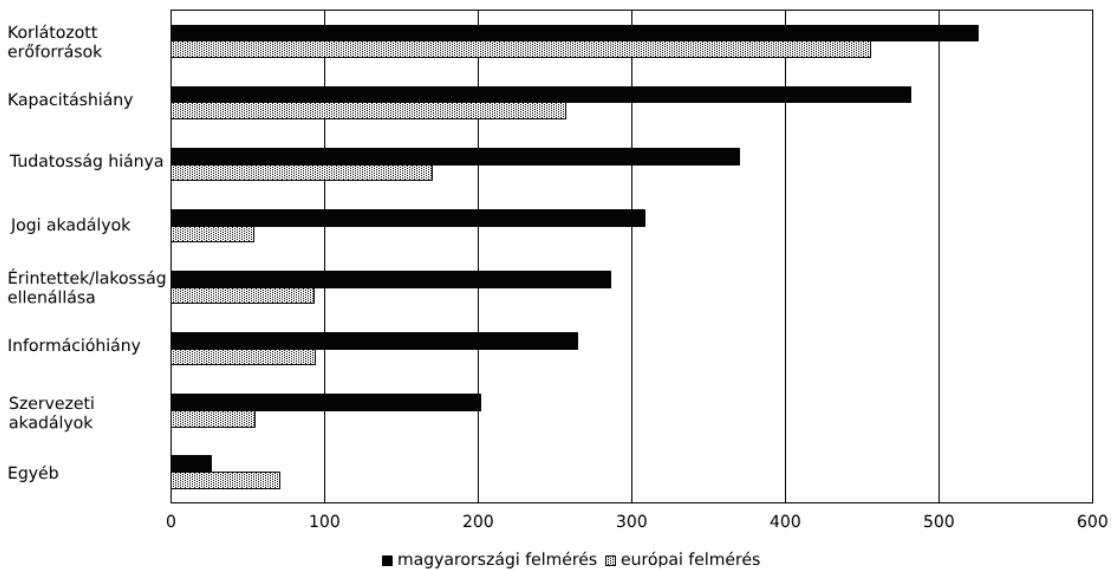

6. ábra: Az inváziós fajok elleni küzdelmet leginkább hátráltató tényezők Magyarország és Európa védett, illetve Natura 2000 területein (kumulatív értékek). 
8. A legfontosabb (legnagyobb kárt okozó) inváziós állatfajok a területen Mind az állatok, mind a növények esetében területenként 5-5 fajt lehetett megnevezni. A magyarországi területekről összesen 30 állatfaj került a legveszélyesebbek közé. A 7. ábra azokat tünteti fel, amelyek legalább két adatlapon szerepeltek.

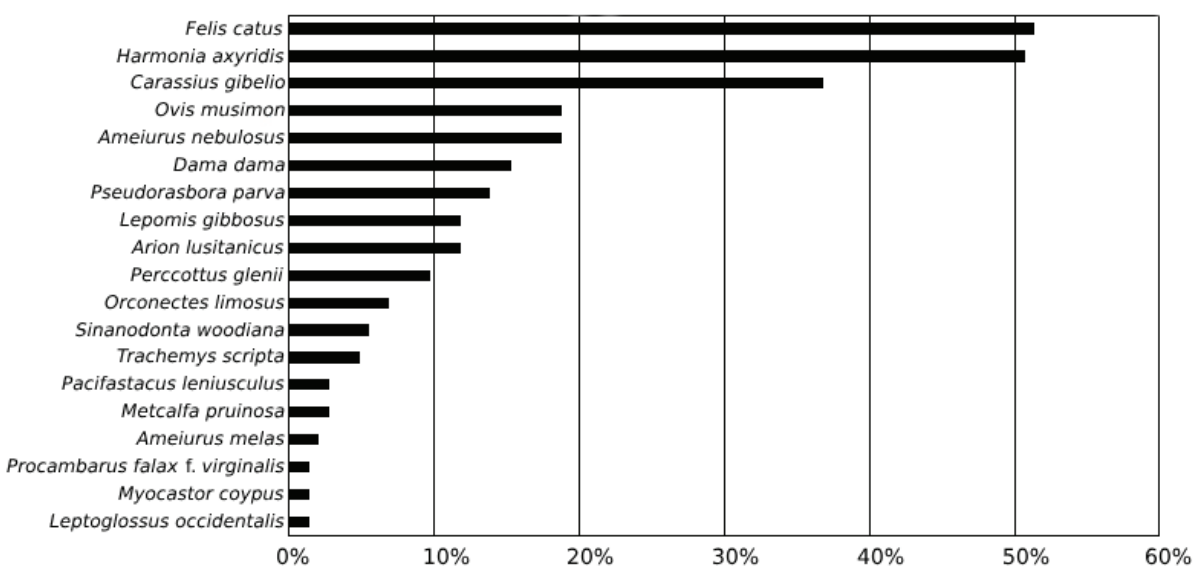

7. ábra: A legveszélyesebb inváziós állatfajok Magyarország védett, illetve Natura 2000 területein.

9. A legfontosabb (legnagyobb kárt okozó) inváziós növényfajok a védett területen A magyarországi területekről összesen 35 növényfaj került a legveszélyesebbek közé. A 8. ábra azokat tünteti fel, amelyek legalább két adatlapon szerepeltek.

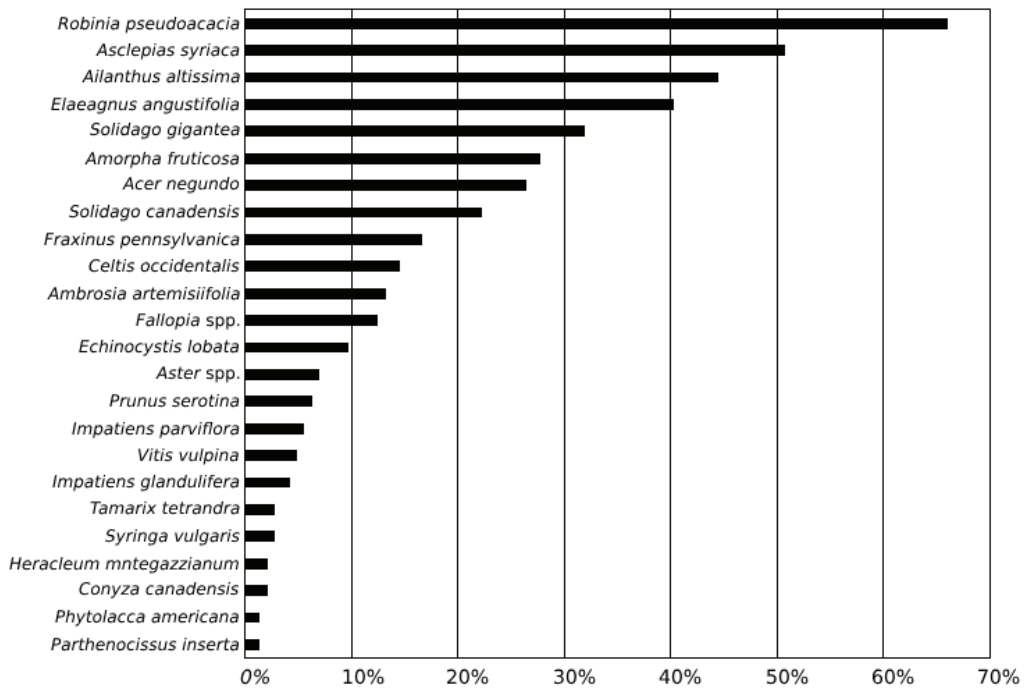

8. ábra: A legveszélyesebb inváziós növényfajok Magyarország védett, illetve Natura 2000 területein. 


\section{Értékelés}

Az alábbiakban az egyes kérdésekre adott válaszokból levonható következtetéseket tárgyaljuk, összehasonlítva a magyarországi eredményeket a Genovesi \& Monaco (2014) által közölt európai eredményekkel.

\section{Veszélyeztetö tényezök (1. ábra)}

Magyarországon a 144 terület közül 139-el (97\%) kapcsolatban adták azt a választ, hogy a veszélyeztető tényezők között valamilyen súllyal szerepet játszanak az inváziós fajok. Az európai vizsgálatnál ez az arány 138-ból 97 terület (70\%) volt. Ha a kumulatív értékeket vesszük figyelembe, az európai vizsgálatnál első helyre került az élőhelyvesztés és fragmentáció, második helyen pedig az inváziós fajok szerepelnek. A magyarországi vizsgálatnál ettől eltérően első helyre kerültek az inváziós fajok. Mindezek alapján nem csak azt állapíthatjuk meg, hogy a védett területeken a biológiai invázió az egyik legnagyobb problémává vált, hanem azt is, hogy Magyarországon az európai átlagnál is sokkal súlyosabb a helyzet.

\section{Inváziós fajokra vonatkozó felmérések (1. táblázat)}

Az inváziós fajokra vonatkozó adatbázisok különösen az állatfajok esetében hiányosak. Magyarország esetében az európai átlagnál is rosszabb a helyzet, az inváziós fajokra csak részlegesen vonatkozó adatbázisokat is figyelembe véve csupán a területek $20 \%$-a rendelkezik ilyen felméréssel. Az állatfajokra vonatkozóan tehát jelentős előrelépésre lenne szükség. A növényfajok esetében kedvezőbb a helyzet. Bár Magyarországon kifejezetten inváziós fajokra vonatkozó felmérés csupán a területek 37\%-ára áll rendelkezésre - szemben az európai 52\%-kal -, de valamilyen, az inváziósokra is vonatkozó felmérésre a területek $85 \%$-án sorkerült.

\section{Inváziós állatfajokat érintő intézkedések (2. ábra)}

Míg az európai vizsgálatban első helyre a monitoring és felügyelet került (a területek 27\%-a), addig Magyarországon a legtöbb területen semmiféle intézkedés nem történt (29\%). A monitoring és felügyelet itt a második helyen szerepel (21\%). Ezt követi az oktatás és kommunikáció (13-13\%). Aktív, az inváziós hatások mérséklésére vonatkozó intézkedések sem az európai, sem a magyarországi területekre nem jellemzők.

\section{Inváziós növényfajokat érintő intézkedések (3. ábra)}

Az inváziós növények kezelése valamivel kedvezőbb képet mutat, csupán 5-6\% azon területek aránya, ahol semmilyen intézkedés nem történt. Az európai felmé- 
résnél itt is a monitoring és felügyelet adott kiugró értéket (24\%) és ezt követi a megfékezés (15\%). Ezzel szemben Magyarországon a területek közel hasonló részarányában történik monitoring (16\%) és megfékezés (17\%), ami azt mutatja, hogy a két tevékenységet - legtöbbször uniós projektek részeként - együtt végzik.

\section{Inváziós fajok hatásai (4. ábra)}

A biológiai invázió legsúlyosabb hatásait tekintve a két felmérés hasonló eredményt hozott, a legsúlyosabb hatásnak az élőhelyek megváltoztatását és az őshonos fajokkal történő versengést tartják a védett területek kezelői.

\section{Leghatékonyabb védekezési módszerek (5. ábra)}

A leghatékonyabbnak tartott módszerek megítélése eltér az európai és a magyarországi válaszadóknál. Míg az első esetben a legfontosabbak a kiirtás, a megfékezés és a megelózés, addig a magyarországi természetvédelmi kezelők legfontosabbnak az élőhelyek helyreállítását tartják. Emellett Magyarországon a jogi szabályozást is nagyobb jelentőségünek ítélik.

\section{Hátráltató tényezők (6. ábra)}

Az inváziós fajok elleni küzdelmet leginkább hátráltató tényezőket mindkét felmérés esetében hasonlóan ítélték meg a védett területek kezelői. Első helyre a források, kapacitások és a tudatosság hiánya került. Eltérést jelent, hogy Magyarországon jelentősebbnek ítélik meg a jogi akadályokat, ami összhangban van azzal, hogy a jogi szabályozás a leghatékonyabbnak ítélt módszerek között is nagyobb értéket kapott.

Legnagyobb veszélyt jelentő inváziós állatfajok (7. ábra)

Az első helyre került két faj közül a házimacska (Felis catus) esetében Csorba (2017) vitatja, hogy háziállatok beilleszthetőek-e az inváziós fajok definíciójába, vagyis hogy idegenhonosnak tekinthetőek-e. A természetvédelmi kezelők ugyanakkor a területek több mint felén (51\%) úgy látták, hogy a legveszélyesebb fajok közé tartozik, aminek oka elsősorban a predációs tevékenysége.

A szintén 51\%-ot elért, kelet-ázsiai eredetü harlekinkaticáról (Harmonia axyridis) Merkl (2017) megállapítja, hogy a bogarak közül az egyetlen olyan jövevényfaj, melynek felbukkanásában a szándékosság szerepet játszott. NyugatEurópába ugyanis szándékosan telepítették be a levéltetvek elleni védekezés céljából, onnan viszont saját erejéből terjeszkedett tovább kelet, dél és észak felé, így érte el hazánkat is 2008-ban. 2011-től tekinthetjük özönfajnak, mert ettől kezdve jelentkezik óriási egyedszámban. Észak-Amerikában és Nyugat-Európában erő- 
2. táblázat: Magyarország védett, illetve Natura 2000 területein legnagyobb kárt okozó inváziós állatfajok listája összehasonlítva más európai listákkal A feltüntetett számok a felmérésben részt vett területek közül az adott faj inváziójával érintettek számát jelöli. Az első 10 helyre került faj vastaggal szedve. ' DAISIE (2009); ${ }^{2}$ Genovesi \& Monaco (2014); ${ }^{3}$ www.termeszetvedelem.hu/ idegenhonos-invazios-fajok. A forrás szerinti különösen veszélyes inváziós gerinces fajokat „,xx” jelöli.; ${ }^{4} \mathrm{Az}$ Unió számára veszélyt jelentő idegenhonos inváziós fajok 1143/2014/EU európai parlamenti és tanácsi rendelet szerinti jegyzékének elfogadásáról szóló 2016/1141. végrehajtási rendelet, és annak bővítéséről szóló 2017/1263 végrehajtási rendelete.

\begin{tabular}{|c|c|c|c|c|c|}
\hline Faj & $\begin{array}{c}\text { Magyarországi } \\
\text { védettterületek (144) }\end{array}$ & $\begin{array}{l}\text { DAISIE } \\
\text { Top } 100^{1}\end{array}$ & $\begin{array}{l}\text { Guidelines }^{2} \\
\quad(138)\end{array}$ & $\begin{array}{l}\text { FM } \\
\text { TMF }^{3}\end{array}$ & Eu $49^{4}$ \\
\hline Felis catus & 74 & & 4 & & \\
\hline Harmonia axyridis & 73 & $\mathrm{x}$ & 6 & $\mathrm{x}$ & \\
\hline Carassius gibelio & 53 & & 5 & $\mathrm{xx}$ & \\
\hline Ovis musimon (aries) & 27 & & 3 & $\mathrm{x}$ & \\
\hline Ameiurus nebulosus & 27 & & & $\mathrm{x}$ & \\
\hline Dama dama & 22 & & 3 & $\mathrm{x}$ & \\
\hline Pseudorasbora parva & 20 & $\mathrm{x}$ & 2 & $\mathrm{x}$ & $\mathrm{x}$ \\
\hline Arion lusitanicus (vulgaris) & 17 & $\mathrm{x}$ & 5 & $\mathrm{x}$ & \\
\hline Lepomis gibbosus & 17 & & 6 & $\mathrm{x}$ & \\
\hline Perccottus glenii & 14 & & & $\mathrm{xx}$ & $\mathrm{x}$ \\
\hline Orconectes limosus & 10 & & 10 & $\mathrm{x}$ & $\mathrm{x}$ \\
\hline Sinanodonta woodiana & 8 & & & $\mathrm{x}$ & \\
\hline Trachemys scripta & 7 & $\mathrm{x}$ & 11 & & $\mathrm{x}$ \\
\hline Metcalfa pruinosa & 4 & & & & \\
\hline Pacifastacus leniusculus & 4 & & 9 & $\mathrm{x}$ & $\mathrm{x}$ \\
\hline Ameiurus melas & 3 & & 4 & $\mathrm{x}$ & \\
\hline Leptoglossus occidentalis & 2 & & 2 & & \\
\hline Myocastor coypus & 2 & $\mathrm{x}$ & 18 & & $\mathrm{x}$ \\
\hline Procambarus falax $f$. virginalis & 2 & & & & $\mathrm{x}$ \\
\hline Anguilla anguilla & 1 & & & & \\
\hline Canis lupus familiaris & 1 & & & & \\
\hline Corbicula sp. (fluminea) & 1 & $\mathrm{x}$ & & $\mathrm{x}$ & \\
\hline $\begin{array}{l}\text { Dreissena sp. (polymorpha, } \\
\text { bugensis) }\end{array}$ & 1 & $\mathrm{x}$ & & $\mathrm{x}$ & \\
\hline $\begin{array}{l}\text { Hypophthalmichthys molitrix } X \\
\text { H. nobilis }\end{array}$ & 1 & & & $\mathrm{x}$ & \\
\hline Neogobius melanostomus & 1 & $\mathrm{x}$ & & & \\
\hline Nyctereutes procyonoides & 1 & $\mathrm{x}$ & 9 & $\mathrm{x}$ & $\mathrm{x}$ \\
\hline Ondatra zibethicus & 1 & $\mathrm{x}$ & 7 & $\mathrm{x}$ & $\mathrm{x}$ \\
\hline Ponticola kessleri & 1 & & & & \\
\hline Potamopyrgus antipodarum & 1 & & & $\mathrm{x}$ & \\
\hline Procyon lotor & 1 & $\mathrm{x}$ & 3 & & $\mathrm{x}$ \\
\hline
\end{tabular}


sen visszaszorította az őshonos katicabogárfajokat, de újabb vizsgálatok szerint e hatása csökkenni látszik. Varga (2017) szerint hatása nem csupán abban áll, hogy az öshonos fajokat, mindenekelött a hétpettyes katicabogarat (Coccinella septempunctata) kiszorítja, hanem predációs tevékenysége az egész rovarközösség összetételét befolyásolja, illetve annak diverzitását csökkenti.

Báldi és Soltész (2017) megállapítása szerint az összes fajszámhoz képest a vízi csoportoknál jelentős, 30\% feletti az inváziós fajok aránya. Felmérésünk eredménye ezzel összhangban van, ugyanis a kérdőíveken jelzett 30 inváziós állatfajból 19 vízben él. A 10 legveszélyesebbnek bizonyult faj közül 5 hal.

Sok területen jelent problémát két vadászati céllal betelepített nagyvad faj, a muflon (Ovis musimon) (19\%) és a dám (Dama dama) (15\%). Bár vannak, akik az archeozoológiai eredmények fényében utóbbi fajnál megkérdőjelezik, hogy idegenhonosnak tekinthető-e (Csorba 2017), természetvédelmi károkozása nyilvánvaló.

Említésre méltó, hogy az első 10 faj fele néhány évtizeden belül érkezett Magyarországra.

A 2. táblázatban látható a magyarországi védett területek kezelőinek adataiból összeállított teljes lista, összehasonlítva több európai listával és az Európai Unió számára veszélyt jelentő idegenhonos inváziós fajok jegyzékével. A 30 faj közül 11 szerepel a DAISIE (2009) 100-as listáján, ami a legveszélyesebb európai inváziós fajokat tartalmazza. 17 faj egyezik a Genovesi és Monaco (2014) felmérésének eredményeként létrejött listával. A 30 fajból 10 megtalálható az Unió jegyzékén is, de a legtöbb magyarországi védett területen veszélyt jelentő faj közül csupán kettő, a kínai razbóra (Pseudorasbora parva) és az amurgéb (Perccottus glenii) szerepel.

Legnagyobb veszélyt jelentö inváziós növényfajok (8. ábra)

A fajok közül kiemelkedik a fehér akác (Robinia pseudoacacia), ami a védett területek 66\%-án szerepel a legnagyobb problémát jelentő fajok között. A 10 legproblémásabb növényfaj közül 8 észak-amerikai eredetủ és 7 fásszárú. Mind a 10 száz évnél régebben került az országba, jellemzően szándékos betelepítés eredményeként. Ebből arra következtethetünk, hogy sikerességüket inváziós képességük mellett a tudatos terjesztés is elösegítette, és mindemellett idejük is volt elterjedni. Érdekes, hogy miközben szakmai vita folyik arról, hogy az ürömlevelü parlagfü (Ambrosia artemisiifolia) megjelenik-e a természetes élőhelyeken, a természetvédelmi kezelők 19 területről jelezték károkozását.

Az 3. táblázatban látható a magyarországi védett területek kezelőinek adataiból összeállított teljes növénylista, összehasonlítva több európai listával és az Európai Unió számára veszélyt jelentő idegenhonos inváziós fajok jegyzékével. A ma- 
gyarországi fajok közül a DAISIE 100-as listáján 8, az EPPO listáin 13, Genovesi és Monaco (2014) listáján 18 szerepel. A listákat egybevetve 15 olyan fajt kapunk, amelyek a legtöbb magyarországi védett területen veszélyt jelentenek, illetve amelyek esetében az európai listák alapján várható a további erôteljes térfoglalás.

A Robinia pseudoacacia a felmérés szerint a legtöbb problémát okozó faj a védett területeinken. Szerepel a DAISIE 100-as listáján és az európai felmérés első 10 legveszélyesebb növényfaja között is.

Az Ailanthus altissima, az Ambrosia artemisiifolia, a Fallopia spp. és a Prunus serotina mind a négy listán szerepel. Érdemes megjegyezni, hogy a bálványfát mindegyiken kiemelt helyen találjuk.

Bár mind a négy listán szerepel az Impatiens glandulifera és a Heracleum mantegazzianum is, mégis érdemes külön említeni ezeket a fajokat, mivel országos léptékben még viszonylag kevés helyen jelentenek komolyabb gondot, de terjedésük jelenleg is zajlik.

Az Asclepias syriaca, az Elaeagnus angustifolia, az Acer negundo, a Fraxinus pennsylvanica és a Celtis occidentalis az európai listák szerint nem játszanak jelentős szerepet, de magyarországi kártételük jól ismert, igen jelentős (Bartha \& Csiszár 2012a,b,c, Bagi \& Bakacsy 2012, Udvardy \& Nótári 2012)

Az Amorpha fruticosa, a Solidago gigantea és a $S$. canadensis a hazai és az európai felmérésben, továbbá az EPPO listáján is szerepelnek. A két Solidago faj a hazai és az európai felmérésben egyaránt az első tízbe került.

Az Echinocystis lobata a magyarországi és az európai felmérésben és a DAISIE 100-as listáján is szerepel.

A fent felsoroltak közül az Európai Unió számára veszélyt jelentő idegenhonos inváziós fajok jegyzékén (1143/2014/EU rendelet által előírt jegyzék) csak az Asclepias syriaca, az Impatiens glandulifera, a Heracleum mantegazzianum szerepel. A magyarországi védett területekről jelzett 34 növényfaj közül rajtuk kívül az egyetlen területről jelzett Hydrocotyle ranunculoides került az uniós listára.

Felmérésünk aktualitását az idegenhonos inváziós fajokkal kapcsolatban megjelenő uniós és tagállami szabályozások, illetve az ezzel összefüggésben készülő inváziós listák adták. Az inváziós fajokkal szembeni fellépés szükségességét, illetve a velük kapcsolatos szabályokat a 2015. január 1-én hatályba lépett 1143/2014/ EU rendelet rögzíti, ennek 4. cikke rendelkezik az Unió számára veszélyt jelentő idegenhonos inváziós fajok jegyzékének összeállításáról. Azokra a fajokra vonatkozóan, amelyek e listára felkerülnek szigorú szabályozás lép életbe, tartásuk, szaporításuk, a velük való kereskedelem stb. gyakorlatilag tilos. Emiatt a jegyzék összeállítása a szakmai megfontolásokon túl gazdasági és politikai kérdés lett. Ezzel magyarázható, hogy a 2016. július 13-án elfogadott, majd 2017. augusztus 
3. táblázat: Magyarország védett, illetve Natura 2000 területein legnagyobb kárt okozó inváziós növényfajok listája összehasonlítva más európai listákkal. A feltüntetett számok a felmérésben részt vett területek közül az adott faj inváziójával érintettek számát jelöli. Az első 10 helyre került faj vastaggal szedve. ${ }^{1}$ DAISIE (2009) ${ }^{2}$ www.eppo.int, inv = inváziós. ${ }^{3}$ Genovesi és Monaco (2014). ${ }^{4}$ Balogh et al. (2004), alk = alkalmai, átal = átalakító, inv= inváziós, meg = meghonosodott. ${ }^{5} \mathrm{www}$. termeszetvedelem.hu/idegenhonos-invazios-fajok. A forrás szerinti legveszélyesebb, különösen nagy természetvédelmi kárt okozó szárazföldi özönnövény fajokat „xx” jelöli. ${ }^{6} \mathrm{Az}$ Unió számára veszélyt jelentő idegenhonos inváziós fajok 1143/2014/EU európai parlamenti és tanácsi rendelet szerinti jegyzékének elfogadásáról szóló 2016/1141. végrehajtási rendelet, és annak bővítéséről szóló 2017/1263 végrehajtási rendelete.

\begin{tabular}{|c|c|c|c|c|c|c|c|}
\hline Faj & $\begin{array}{c}\text { Magyarországi } \\
\text { védett területek } \\
\text { (144) }\end{array}$ & $\begin{array}{l}\text { DAISIE } \\
\text { Top } 100^{1}\end{array}$ & $\mathrm{EPPO}^{2}$ & $\begin{array}{l}\text { Guidelines }^{3} \\
\text { (138) }\end{array}$ & $\begin{array}{l}\text { Neofitonok } \\
\text { jegyzéke }\end{array}$ & $\begin{array}{l}\text { FM } \\
\text { TMF }^{5}\end{array}$ & Eu $49^{6}$ \\
\hline Robinia pseudoacacia & 95 & $\mathrm{x}$ & & 26 & átal & $\mathrm{xx}$ & \\
\hline Asclepias syriaca & 73 & & & 3 & átal & $x x$ & $\mathrm{x}$ \\
\hline Ailanthus altissima & 64 & $\mathrm{x}$ & inv & 16 & átal & $\mathrm{xx}$ & \\
\hline Elaeagnus angustifolia & 58 & & & & átal & $\mathrm{xx}$ & \\
\hline Solidago gigantea & 46 & & inv & 8 & átal & $\mathrm{xx}$ & \\
\hline Amorpha fruticosa & 40 & & inv & 6 & átal & $\mathrm{xx}$ & \\
\hline Acer negundo & 38 & & & 6 & átal & $\mathrm{xx}$ & \\
\hline Solidago canadensis & 32 & & inv & 9 & átal & $\mathrm{x}$ & \\
\hline Fraxinus pennsylvanica & 24 & & & & átal & $\mathrm{xx}$ & \\
\hline Celtis occidentalis & 21 & & & & átal & $\mathrm{x}$ & \\
\hline Ambrosia artemisiifolia & 19 & $\mathrm{x}$ & inv & 10 & átal & & \\
\hline Fallopia spp. & 18 & $\mathrm{x}$ & inv & 48 & átal & $\mathrm{xx}$ & \\
\hline Echinocystis lobata & 14 & $\mathrm{x}$ & & 4 & átal & $\mathrm{xx}$ & \\
\hline Aster spp. & 10 & & & 2 & átal & $\mathrm{xx}$ & \\
\hline Prunus serotina & 9 & $\mathrm{x}$ & inv & 5 & inv & $\mathrm{xx}$ & \\
\hline Impatiens parviflora & 8 & & pot & 5 & inv & $\mathrm{x}$ & \\
\hline Vitis vulpina & 7 & & & & átal & $\mathrm{x}$ & \\
\hline Impatiens glandulifera & 6 & $\mathrm{x}$ & inv & 29 & átal & $\mathrm{xx}$ & $\mathrm{x}$ \\
\hline Syringa vulgaris & 4 & & & & megh & & \\
\hline Tamarix tetrandra & 4 & & & & alk & & \\
\hline Conyza canadensis & 3 & & & & átal & & \\
\hline $\begin{array}{l}\text { Heracleum } \\
\text { mantegazzianum }\end{array}$ & 3 & $\mathrm{x}$ & inv & 11 & átal & $\mathrm{x}$ & $\mathrm{x}$ \\
\hline Parthenocissus inserta & 2 & & & & átal & $\mathrm{x}$ & \\
\hline Phytolacca americana & 2 & & & 4 & átal & $\mathrm{x}$ & \\
\hline Elymus elongatus & 1 & & & & & & \\
\hline Forsythia $\times$ intermedia & 1 & & & & alk & & \\
\hline Helianthus tuberosus & 1 & & inv & 2 & átal & $\mathrm{xx}$ & \\
\hline
\end{tabular}


3. táblázat (folytatás): Magyarország védett, illetve Natura 2000 területein legnagyobb kárt okozó inváziós növényfajok listája összehasonlítva más európai listákkal A rövidítések felsorolását lásd fentebb.

\begin{tabular}{|c|c|c|c|c|c|c|c|}
\hline Faj & $\begin{array}{c}\text { Magyarországi } \\
\text { védett területek } \\
\text { (144) }\end{array}$ & $\begin{array}{l}\text { DAISIE } \\
\text { Top } 100^{1}\end{array}$ & $\mathrm{EPPO}^{2}$ & $\begin{array}{l}\text { Guidelines }{ }^{3} \\
\text { (138) }\end{array}$ & $\begin{array}{l}\text { Neofitonok } \\
\text { jegyzéke }^{4}\end{array}$ & $\begin{array}{l}\text { FM } \\
\text { TMF }^{5}\end{array}$ & Eu $49^{6}$ \\
\hline Laburnum anagyroides & 1 & & & & & & \\
\hline Lycium barbarum & 1 & & & & & & \\
\hline Mahonia aquifoium & 1 & & & & alk & & \\
\hline Pinus nigra & 1 & & & & megh & & \\
\hline Sorghum halepense & 1 & & & & átal & & \\
\hline Xanthium spinosum & 1 & & & & inv & & \\
\hline Azolla filiculoides & 1 & & & 6 & megh & $\mathrm{x}$ & \\
\hline $\begin{array}{l}\text { Hydrocotyle } \\
\text { ranunculoides }\end{array}$ & 1 & & & & & & $\mathrm{x}$ \\
\hline
\end{tabular}

2-án bővített, összesen 48 fajt tartalmazó lista csalódást okozott a természetvédelmi szakemberek számára. Mint ahogy a jelen felmérés is mutatja, a természetvédelmi szempontból valós problémát jelentő fajok közül nagyon kevés szerepel rajta. Véleményünk szerint megoldást jelenthet a regionális, illetve nemzeti jegyzékek differenciált összeállítása, vagyis, ha többféle listát hozunk létre, melyekre eltérő szabályozás vonatkozik. Szükségesnek tartjuk külön kezelni azokat a fajokat, amelyeknél az elérni kívánt cél a teljes kiirtás és azokat, amelyeknél a cél az, hogy a védett és Natura 2000 területekről, illetve ezek puffer zónájából kiszorítsuk őket. A szerzők erre vonatkozó gyakorlati javaslatát Korda et al. (2017) közli.

Köszönetnyilvánítás - Köszönettel tartozunk Andrea Monaconak, aki rendelkezésünkre bocsájtotta vizsgálatuk adatait, továbbá a magyarországi nemzeti park igazgatóságok dolgozóinak, akik adatközléssel segítették munkánkat. A kutatás a LIFE10NAT/HU/000020 LIFE számú pályázat támogatásával valósult meg. A Soproni Egyetem munkatársait a „Soproni Egyetem Struktúraváltási Terve” - 32388-2/2017 INTFIN sz. projekt keretében az Emberi Erőforrások Minisztériuma támogatta.

\section{Irodalomjegyzék}

Bagi, I. \& Bakacsy, L. (2012): Közönséges selyemkóró (Asclepias syriaca L.). - In: Csiszár, Á. (eds): Inváziós növényfajok Magyarországon. Nyugat-magyarországi Egyetem Kiadó, Sopron, pp. $182-187$.

Báldi, A. \& Soltész, Z. (2017): Behurcolt és invazív állatfajok Magyarországon - összefoglalás és kitekintés. - Magyar Tudomány 178: 433-437. 
Balogh, C., Muskó, I. B., Tóth, L. \& Nagy, L. (2008): Quantitative trends of zebra mussels in Lake Balaton (Hungary) in 2003-2005 at different water levels. - Hydrobiologia 613: 57-69. doi: https://doi.org/10.1007/s10750-008-9472-3

Balogh, L., Dancza, I. \& Király, G. (2004): A magyarországi neofitonok időszerü jegyzéke és besorolásuk inváziós szempontból. - In: Mihály, B. \& Botta-Dukát, Z. (eds): Biológiai inváziók Magyarországon. Özönnövények. TermészetBÚVÁR Kiadó, Budapest, pp. 61-92.

Balogh, L., Dancza, I. \& Király, G. (2008): Preliminary report on the grid-based mapping of invasive plants in Hungary. - Neobiota 7: 105-114.

Balogh, L. (2001): Invasive alien plants threatening the natural vegetation of Örség Landscape Protection Area (Hungary). - In: Brundu, G., Brock, J., Camarda, I., Child, L. \& Wade, M. (eds): Plant invasions: species ecology and ecosystem management. Backhuys Publishers, Leiden, pp.185-197.

Bartha, D. \& Csiszár, Á. (2012a): Nyugati ostorfa (Celtis occidentalis L.). - In: Csiszár, Á. (eds): Inváziós növényfajok Magyarországon. Nyugat-magyarországi Egyetem Kiadó, Sopron, pp. 109-113.

Bartha, D. \& Csiszár, Á. (2012b): Keskenylevelü ezüstfa (Elaeagnus angustifolia L.). - In: Csiszár, Á. (eds): Inváziós növényfajok Magyarországon. Nyugat-magyarországi Egyetem Kiadó, Sopron, pp. 115-119.

Bartha, D. \& Csiszár, Á. (2012c): Amerikai kőris (Fraxinus pennsylvanica Marsh.). - In: Csiszár, Á. (eds): Inváziós növényfajok Magyarországon. Nyugat-magyarországi Egyetem Kiadó, Sopron, pp. 195-199.

Bartha, D., Király, G., Schmidt, D., Tiborcz, V., Barina, Z., Csiky, J., Jakab, G., Lesku, B., Schmotzer, A., Vidéki, R., Vojtkó, A. \& Zólyomi, Sz. (eds) (2015): Magyarország edényes növényfajainak elterjedési atlasza. - Nyugat-magyarországi Egyetem Kiadó, Sopron, 330 p.

Bódis, E., Borza, P., Potyó, I., Puky, M., Weipert, A. \& Guti, G. (2012): Invasive mollusc, crustacean, fish and reptile species along the Hungarian section of the River Danube and some connected waters. - Acta. Zool. Acad. Sci. H. 58: 29-45.

Bódis, E., Nosek, J., Oertel, N., Tóth, B. \& Fehér, Z. (2011a): A comparative study of two Corbicula morphs (Bivalvia, Corbiculidae) inhabiting River Danube. - Int. Rev. Hydrobiol. 96: 257-273. doi: https://doi.org/10.1002/iroh.201111344

Bódis, E., Nosek, J., Oertel, N., Tóth, B., Hornung, E. \& Sousa, R. (2011b): Spatial distribution of bivalves in relation to environmental conditions (Middle Danube catchment, Hungary). - Community Ecol. 12: 210-219. doi: https:// doi.org/ 10.1556/ComEc.12.2011.2.9

Bódis, E, Tóth, B. \& Sousa, R. (2014): Impact of Dreissena fouling on the physiological condition of native and invasive bivalves: interspecific and temporal variations. - Biol. Invasions 16: 1373-1386. doi: https://doi.org/10.1007/s10530-013-0575-Z

Bódis, E. (2007) The biomass dynamics of Corbicula fluminea invasive mussel. - Acta Biol. Debr. Oecol. Hung. 16: 9-20.

Borza, P. (2009): First record of the Ponto-Caspian amphipod Echinogammarus trichiatus (Martynov, 1932) (= Chaetogammarus trichiatus) (Crustacea: Amphipoda) for the Middle-Danube (Slovakia and Hungary). - Aquat. Invasions 4: 693-696. doi: https:// doi.org/10.3391/ai.2009.4.4.17

Borza, P. (2011): Revision of invasion history, distributional patterns, and new records of Corophiidae (Crustacea: Amphipoda) in Hungary. - Acta zool. hung. 57: 75-84.

Borza, P., Czirok, A., Deák, C., Ficsór, M., Horvai, V., Horváth, Z., Juhász, P., Kovács, K., Szabó, T. \& Vad, C. F. (2011): Invasive mysids (Crustacea: Malacostraca: Mysida) in Hungary: distributions and dispersal mechanisms. - North-West J. of Zool. 7: 222-228. 
Botta-Dukát, Z. \& Mihály, B. (eds) (2006): Biológiai inváziók Magyarországon. Özönnövények II. A KvVM Természetvédelmi Hivatalának Tanulmánykötetei 10. - Line \& More Kft., Budapest, $412 \mathrm{pp}$.

Botta-Dukát, Z. (2008): Invasion of alien species to Hungarian (semi-) natural habitats. - Acta. Bot. Hung. 50: 219-227. doi: https://doi.org/10.1556/ABot.50.2008.Suppl.11

Botta-Dukát, Z. (2017): A magyarországi behurcolt és inváziós növényekre vonatkozó ismeretek összegyüjtésének tapasztalatai. - Magyar Tudomány 178: 395-398.

Csányi, B. (1999): Spreading invaders along the Hungarian highway: first record of Corbicula fluminea (O.F. Müller, 1774) and Corbicula fluminalis (O.F. Müller, 1774) in Hungary (Mollusca: Bivalvia). - F. Hist. Musei Matraensis 23: 343-345.

Csecserits, A., Botta-Dukát, Z., Kröel-Dulay, Gy., Lhotsky, B., Ónodi, G., Rédei, T. \& Halassy, M. (2016): Tree plantations are hot-spots of plant invasion in a landscape with heterogenous landuse. - Agr. Ecosyst. Environ. 226: 88-89. doi: https://doi.org/10.1016/j.agee.2016.03.024

Csiszár, Á.(eds) (2012): Inváziós növényfajok Magyarországon. - Nyugat-magyarországi Egyetem Kiadó, Sopron, 364 pp.

Csiszár, Á. \& Korda, M. (eds) (2015): Practical Experiences in Invasive Alien Plant Control. Rosalia Handbooks 3. - Duna-Ipoly Nemzeti Park Directorate, Budapest, 241 p.

Csóka, Gy., Csókáné Hirka, A. \& Szőcs, L. (2012): Rovarglobalizáció a magyar erdőkben. Erdészettudományi Közl. 2: 187-198.

Csorba, G. (2017): Mit csinálnak az emlős özönfajok Magyarországon? - Magyar Tudomány 178: 430-433.

DAISIE (2009): Handbook of Alien Species in Europe. - Springer, Dordrecht, 399 pp.

EPPO (2017): https://www.eppo.int/INVASIVE PLANTS/ias lists.htm [Hozzáférés: 2017. 12. 30.]

Genovesi, P. \& Monaco, A. (2014): European guidelines on protected areas and invasive alien species. - Council of Europe and Regional Parks Agency, Strasbourg, Rome, 58 p.

Kazinczi, G., Béres, I., Novák, R., Bíro, K. \& Pathy, Z. (2008): Common ragweed (Ambrosia artemisiifolia): a review with special regards to the results in Hungary. I. Taxonomy, origin and distribution, morphology, life cycle and reproduction strategy. - Herbologia 9: 55-91.

Király, G., Steták, D. \& Bányász, D. (2008): Spread of invasive macrophytes in Hungary. Neobiota 7: 123-130.

Korda, M., Kézdy, P. \& Csiszár, Á. (2017): Idegenhonos, inváziós fajok hazánk védett területein. Erdészeti Lapok 152: 107-109.

Merkl, O. (2017): Kártevő bogárjövevények Magyarországon: pillanatfelvétel 2016-ban. - Magyar Tudomány 178: 402-405.

Mihály, B. \& Botta-Dukát, Z. (eds) (2004): Biológiai inváziók Magyarországon. Özönnövények. A KvVM Természetvédelmi Hivatalának Tanulmánykötetei 9. - TermészetBÚVÁR Alapítvány Kiadó, Budapest, 408 p.

Muskó, I. B, Balogh, Cs., Tóth, Á. P., Varga, É. \& Lakatos, Gy. (2007): Differential response of invasive malacostracan species to lake level fluctuations. - Hydrobiologia 590: 65-74. doi: https://doi.org/10.1007/s10750-007-0758-7

Muskó, I. B. \& Bakó, B. (2005): The density and biomass of Dreissena polymorpha living on submerged macrophytes in Lake Balaton (Hungary). - Arc. Hydrobiol. 162: 229-251. doi: https:// doi.org/10.1127/0003-9136/2005/0162-0229

Muskó, I. B., Bence, M. \& Balogh, Cs. (2008): Occurrence of a new Ponto-Caspian species, Cordylophora caspia (Pallas, 1771) (Hydrozoa: Clavidae) in Lake Balaton(Hungary). - Acta Biol. Debr. Oecol. Hung. 54: 169-179.

Papp, L. (2017): Behurcolt és invazív állatok Magyarországon. Bevezető. - Magyar Tudomány 178: $386-387$. 
Ripka, G. (2010): Jövevény kártevő ízeltlábúak áttekintése Magyarországon. - Növényvédelem 46: $45-58$.

Szeőke, K. \& Csóka, Gy. (2012): Jövevény kártevő ízeltlábúak áttekintése Magyarországon Lepkék (Lepidoptera). - Növényvédelem 48: 105-115.

Takács, P., Czeglédi, I., Ferincz, Á., Sály, P., Specziár, A., Vitál, Z., Weiperth, A. \& Erős, T. (2017): Non-native fish species in Hungarian waters: historical overview, potential sources and recent trends in their distribution. - Hydrobiologia 795: 1-22. doi: https://doi.org/.1007/s10750-0173147-x

Természetvédelem (2017): www.termeszetvedelem.hu/idegenhonos-invazios-fajok [Hozzáférés: 2017. 12. 30.]

Török, K., Botta-Dukát, Z., Dancza, I., Németh, I., Kiss, J., Mihály, B. \& Magyar, D. (2003): Invasion Gateways and Corridors in the Carpathian Basin: Biological Invasions in Hungary. - Biol. Invasions 5: 349-356. doi: https://doi.org/10.1023/B:BINV.0000005570.19429.73

Tuba, K., Horváth, B. \& Lakatos, F. (2012): Inváziós rovarok fás növényeken. - Nyugat-magyarországi Egyetem Kiadó, Sopron, 120 p.

Udvardy, L. \& Nótári, K. (2012): Zöld juhar (Acer negundo L.). - In: Csiszár, Á. (eds): Inváziós növényfajok Magyarországon. Nyugat-magyarországi Egyetem Kiadó, Sopron, pp. 145-149.

Varga, Z. (2017): A biológiai invázió általános kérdései - Magyar Tudomány 178: 388-394.

Weiperth, A., Csányi, B., György, Á., Szekeres, J., Friedrich, T. \& Szalóky, Z. (2011): Observation of the sturgeon hybrid (Acipenser naccarii $\times$ Acipenser baerii) in the Hungarian section of River Danube. - Pisces Hungarici 8: 111-112.

Weiperth, A., Czeglédi, I., Ferincz, Á., Gál, B., Sály, P., Specziár, A., Staszny, Á., Takács, P., Vitál, Z. \& Erős, T. (2017): Idegenhonos halfajok megjelenése és terjedése. - In: Holes, A. (eds): Magyarország környezeti állapota. Herman Ottó Intézet, Budapest, pp. 91-105. 


\title{
Occurrence and management of invasive alien species in Hungarian protected areas compared to Europe
}

\author{
Pál Kézdy ${ }^{1}$, Ágnes Csiszár ${ }^{2}$, Márton Korda² and Dénes Bartha ${ }^{2}$ \\ ${ }^{1}$ Duna-Ipoly National Park Directorate H-1121 Budapest, Költö u. 21. \\ ${ }^{2}$ University of Sopron, Faculty of Forestry, Department of Botany and Nature \\ Conservation H-9400 Sopron, Bajcsy-Zsilinszky u. 4. \\ e-mail:kezdyp@dinpi.hu
}

We carried out a questionnaire among Hungarian PA managers in order to examine the problems caused by invasive alien species (IAS) in Hungarian protected areas (PA). Altogether results from 144 PAs were evaluated and compared with the survey of Genovesi and Monaco (2014), who elaborated answers concerning 138 PAs from 21 European countries (excluding Hungary). Evaluating the European results, the first most important threats are habitat loss and fragmentation, and second are IAS. In contrast, the Hungarian respondents put IAS in first place.

Considering animal species, only $20 \%$ of Hungarian PAs have studies aimed at IAS. Whereas monitoring and surveillance take first place in the European survey, there was no management activity in the majority of Hungarian PAs. Domestic cat and harlequin ladybird (Harmonia axyridis) were mentioned as the top invasive (most harmful) animal species in most PAs. There are five fish and two big game species introduced for hunting purpose among the top invasive species.

The state of invasive plant management is much more favourable; only $5-6 \%$ of PAs are not affected by any control activities. Among plant species, the most significant is black locust (Robinia pseudoacacia), which was marked as a harmful species in $66 \%$ of the PAs. Concerning the top ten, 8 species with North American origin and 7 woody species are mentioned by the respondents. Their invasion success could be explained not only by effective spreading strategies, but by intentional cultivation and long residence time.

As our survey shows, the species causing real nature conservation problems are hardly present on the List of IAS of Union Concern. In our opinion, real improvement could be reached by the compilation of a variety of national lists with different regulation and restriction systems. We feel it is necessary to distinguish between species targeted for full eradication and species targeted for control in PAs, Natura 2000 areas and their buffer zones only.

Keywords: biological invasion, invasive alien species, Natura 2000, protected areas, questionnaire, Robinia pseudoacacia 